\title{
Microbial Enrichment of Vermicompost
}

\author{
Kuppuraj Rajasekar, ${ }^{1}$ Thilagavathy Daniel, ${ }^{2}$ and Natchimuthu Karmegam ${ }^{3}$ \\ ${ }^{1}$ Faculty of Science, Vinayaka Missions University, Tamil Nadu, Salem 636 308, India \\ ${ }^{2}$ Department of Biology, Gandhigram Rural Institute-Deemed University, Tamil Nadu, Gandhigram 624 301, India \\ ${ }^{3}$ Department of Botany, Government Arts College, Tamil Nadu, Salem 636 007, India
}

Correspondence should be addressed to Natchimuthu Karmegam, kanishkarmegam@gmail.com

Received 12 January 2012; Accepted 31 January 2012

Academic Editors: Z. He and W. Peijnenburg

Copyright (๑) 2012 Kuppuraj Rajasekar et al. This is an open access article distributed under the Creative Commons Attribution License, which permits unrestricted use, distribution, and reproduction in any medium, provided the original work is properly cited.

\begin{abstract}
The present study has been conducted to explore the possibility of enrichment of vermicompost with microbial inoculants (i.e., biofertilizer organisms), Azospirillum brasilense and Rhizobium leguminosarum, optimization of inoculum level, and time of inoculation during vermicomposting. The survival rate of each microbial inoculant, total microbial population in vermicompost, and their correlation with the microbial inoculants during the storage period (180 days) were assessed. The change in population of $A$. brasilense and $R$. leguminosarum in vermicompost (at 30,35, and $40 \mathrm{~mL} / 175 \mathrm{~g}$ substrates) with reference to storage period showed highly significant negative correlation $(P<0.001)$. The total microbial population in $A$. brasilense and $R$. leguminosarum inoculated vermicompost was high during initial phases of storage and then total microbial population declined towards the end. The inoculum level of $A$. brasilense and $R$. leguminosarum at $35 \mathrm{~mL}$ per $175 \mathrm{~g}$ vermibed substrate is sufficient to maintain $1 \times 10^{7}$ viable cells up to 160 days after ther harvesting of vermicompost. The inoculum of these two biofertilizer organisms into vermibed on the 30th day showed increased survival rate and, hence, the optimized inoculation of $35 \mathrm{~mL}$ of inoculum per $175 \mathrm{~g}$ substrate on the 30 th day of vermicomposting is helpful for the maintenance of sufficient viable population for more than five months in the enriched vermicompost.
\end{abstract}

\section{Introduction}

The compost prepared from organic materials using earthworms is a low cost and ecofriendly technology called vermicomposting. The fine granular peat-like end product, vermicompost that is produced is reported to contain elevated levels of nitrogen, phosphorus, and potassium (NPK) in available form, micronutrients, microflora, enzymes, and growth regulators $[1,2]$. Because of this, the vermicompost when applied or supplemented in soil improves crop growth and yield $[3,4]$. The earthworms, the drivers of many processes in soil, apart from the known vermicomposting, are also found to enhance phytoextraction of metals from contaminated soils [5]. In addition, vermicompost, produced by the joint action of earthworms and microbes, contains nutrients in available form with increased microbial activity [6].

The use of biofertilizers is nowadays known to bring out several benefits to soil: solubilization of essential minerals, get hold of nutrients, offering micronutrients in more utilizable form for plants, and taking part in biological nitrogen fixation. Microorganisms of this group are generally known as plant growth promoting microorganisms (PGPMs) which include Azospirillum, Azotobacter, phosphobacteria, Rhizobia, and cyanobacteria. The PGPMs are capable of putting forth advantageous properties on growth and yield characteristics of several cultivable crops in different parts of the world [7-9]. Rhizosphere bacteria promote plant growth by improving the availability of nutrients suppressing the growth of plant pathogens or by production of hormones such as auxins [10]. In laboratory, the biofertilizers are mass multiplied in large scale using traditional culture medium and/or chief source supplemented medium for agricultural purposes [11-13]. Recently, Raja Sekar and Karmegam [14] reported that the vermicasts are able to increase the survival rate of biofertilizer organisms for more than a year when used as carrier material. 
TABLE 1: The viable population of $A$. brasilense inoculated at the rate of $30 \mathrm{~mL}$ per $175 \mathrm{~g}$ of substrate in different intervals along the storage period of vermicompost. Values are rounded of mean values of three replicates. The values with same superscript letters between columns are not significantly different at $5 \%$ level $(P<0.05)$ by Duncan's multiple-range test.

\begin{tabular}{|c|c|c|c|c|}
\hline \multirow{2}{*}{$\begin{array}{l}\text { Storage period of vermicompost } \\
\text { (after harvest, in days) }\end{array}$} & \multicolumn{4}{|c|}{$\begin{array}{l}\text { Viable population of } A \text {. brasilense }\left(\mathrm{CFU} \times 10^{7} \mathrm{~g}^{-1}\right) \\
\text { Time of inoculation (vermicomposting days) }\end{array}$} \\
\hline & 0th day & 10th day & 20th day & 30th day \\
\hline 0 & $9^{a}$ & $11^{\mathrm{a}, \mathrm{b}}$ & $12^{\mathrm{b}}$ & $9^{a}$ \\
\hline 15 & $9^{a}$ & $9^{a}$ & $11^{\mathrm{a}, \mathrm{b}}$ & $13^{\mathrm{b}}$ \\
\hline 30 & $8^{\mathrm{a}}$ & $9^{\mathrm{a}, \mathrm{b}}$ & $10^{\mathrm{a}, \mathrm{b}}$ & $11^{\mathrm{b}}$ \\
\hline 45 & $7^{\mathrm{a}}$ & $8^{\mathrm{a}, \mathrm{b}}$ & $9^{\mathrm{a}, \mathrm{b}}$ & $10^{\mathrm{b}}$ \\
\hline 60 & $7^{\mathrm{a}}$ & $8^{a}$ & $8^{\mathrm{a}}$ & $9^{a}$ \\
\hline 75 & $5^{\mathrm{a}}$ & $7^{\mathrm{a}, \mathrm{b}}$ & $8^{\mathrm{b}}$ & $8^{\mathrm{b}}$ \\
\hline 90 & $3^{\mathrm{a}}$ & $4^{\mathrm{a}, \mathrm{b}}$ & $6^{\mathrm{b}}$ & $7^{\mathrm{b}}$ \\
\hline 105 & $2^{\mathrm{a}}$ & $3^{\mathrm{a}, \mathrm{b}}$ & $6^{\mathrm{b}}$ & $6^{\mathrm{b}}$ \\
\hline 120 & $3^{\mathrm{a}}$ & $2^{\mathrm{a}}$ & $4^{\mathrm{a}}$ & $5^{\mathrm{a}}$ \\
\hline 135 & $0^{\mathrm{a}}$ & $0^{\mathrm{a}}$ & $2^{\mathrm{a}, \mathrm{b}}$ & $3^{b}$ \\
\hline 150 & $0^{\mathrm{a}}$ & $0^{\mathrm{a}}$ & $1^{\mathrm{a}}$ & $2^{\mathrm{a}}$ \\
\hline 165 & $0^{\mathrm{a}}$ & $0^{\mathrm{a}}$ & $0^{\mathrm{a}}$ & $1^{\mathrm{a}}$ \\
\hline 180 & $0^{\mathrm{a}}$ & $0^{\mathrm{a}}$ & $0^{\mathrm{a}}$ & $0^{\mathrm{a}}$ \\
\hline
\end{tabular}

TABLE 2: The viable population of $A$. brasilense inoculated at the rate of $35 \mathrm{~mL}$ per $175 \mathrm{~g}$ of substrate in different intervals along the storage period of vermicompost. Values are rounded of mean values of three replicates. The values with same superscript letters between columns are not significantly different at $5 \%$ level $(P<0.05)$ by Duncan's multiple-range test.

\begin{tabular}{|c|c|c|c|c|}
\hline \multirow{2}{*}{$\begin{array}{l}\text { Storage period of vermicompost } \\
\text { (after harvest, in days) }\end{array}$} & \multicolumn{4}{|c|}{$\begin{array}{l}\text { Viable population of } A \text {. brasilense }\left(\mathrm{CFU} \times 10^{7} \mathrm{~g}^{-1}\right) \\
\text { Time of inoculation (vermicomposting days) }\end{array}$} \\
\hline & 0th day & 10th day & 20th day & 30th day \\
\hline 0 & $10^{\mathrm{a}}$ & $11^{\mathrm{a}}$ & $12^{\mathrm{a}}$ & $9^{a}$ \\
\hline 15 & $9^{a}$ & $10^{\mathrm{a}}$ & $11^{\mathrm{a}, \mathrm{b}}$ & $15^{\mathrm{b}}$ \\
\hline 30 & $9^{\mathrm{a}}$ & $9^{a}$ & $10^{\mathrm{a}, \mathrm{b}}$ & $12^{\mathrm{a}, \mathrm{b}}$ \\
\hline 45 & $7^{\mathrm{a}}$ & $9^{\mathrm{a}, \mathrm{b}}$ & $8^{\mathrm{a}, \mathrm{b}}$ & $10^{\mathrm{b}}$ \\
\hline 60 & $7^{\mathrm{a}}$ & $8^{\mathrm{a}}$ & $8^{\mathrm{a}}$ & $9^{a}$ \\
\hline 75 & $6^{\mathrm{a}}$ & $7^{\mathrm{a}}$ & $7^{\mathrm{a}}$ & $8^{\mathrm{a}}$ \\
\hline 90 & $5^{\mathrm{a}}$ & $5^{\mathrm{a}}$ & $5^{\mathrm{a}}$ & $7^{\mathrm{a}}$ \\
\hline 105 & $4^{\mathrm{a}}$ & $5^{\mathrm{a}, \mathrm{b}}$ & $5^{\mathrm{a}, \mathrm{b}}$ & $7^{\mathrm{b}}$ \\
\hline 120 & $4^{\mathrm{a}}$ & $4^{\mathrm{a}}$ & $5^{\mathrm{a}}$ & $6^{\mathrm{a}}$ \\
\hline 135 & $1^{\mathrm{a}}$ & $2^{\mathrm{a}, \mathrm{b}}$ & $3^{\mathrm{a}, \mathrm{b}}$ & $4^{\mathrm{b}}$ \\
\hline 150 & $0^{\mathrm{a}}$ & $0^{\mathrm{a}}$ & $1^{\mathrm{a}, \mathrm{b}}$ & $2^{b}$ \\
\hline 165 & $0^{\mathrm{a}}$ & $0^{\mathrm{a}}$ & $0^{\mathrm{a}}$ & $1^{\mathrm{a}}$ \\
\hline 180 & $0^{\mathrm{a}}$ & $0^{\mathrm{a}}$ & $0^{\mathrm{a}}$ & $0^{\mathrm{a}}$ \\
\hline
\end{tabular}

The process of vermicomposting results in the increase of microbial diversity and activity dramatically and the vermicompost produced could be a source of plant growth regulators produced by interactions between microorganisms and earthworms, which could contribute significantly to increased plant growth, flowering, and yields [15]. So, the addition or enrichment of microbial inoculants such as biofertilizers would provide an increased plant growth and yield. The studies on the microbial enrichment of vermicompost with reference to the amount of inoculum required, time of inoculation, survival rate of inoculated microorganisms in vermicompost during storage and the relation of total microbial population with that of inoculated microorganisms are not documented. Hence, the present study has been undertaken to optimize the inoculum level and time of inoculation of biofertilizers in enrichment process of vermicompost and assessing the survival rate of A. brasilense, and $R$. leguminosarum in enriched vermicompost in relation to total microbial population.

\section{Materials and Methods}

2.1. Collection of Biogas Slurry. Biogas slurry for the study was collected from the biogas plant situated at Kottagoundanpatty, Salem (Dt.), Tamil Nadu, and used for the preparation of vermibed. One-week-aged biogas slurry was collected, air-dried, and stored in polyethylene bags until use. 
TABLE 3: The viable population of $A$. brasilense inoculated at the rate of $40 \mathrm{~mL}$ per $175 \mathrm{~g}$ of substrate in different intervals along the storage period of vermicompost. Values are rounded of mean values of three replicates. The values with same superscript letters between columns are not significantly different at $5 \%$ level $(P<0.05)$ by Duncan's multiple-range test.

\begin{tabular}{|c|c|c|c|c|}
\hline \multirow{2}{*}{$\begin{array}{l}\text { Storage period of vermicompost } \\
\text { (after harvest, in days) }\end{array}$} & \multicolumn{4}{|c|}{$\begin{array}{l}\text { Viable population of } A \text {. brasilense }\left(\mathrm{CFU} \times 10^{7} \mathrm{~g}^{-1}\right) \\
\text { Time of inoculation (vermicomposting days) }\end{array}$} \\
\hline & 0th day & 10th day & 20th day & 30th day \\
\hline 0 & $14^{\mathrm{a}, \mathrm{c}}$ & $15^{\mathrm{a}}$ & $18^{\mathrm{b}}$ & $12^{c}$ \\
\hline 15 & $12^{\mathrm{a}}$ & $14^{\mathrm{a}, \mathrm{b}}$ & $15^{\mathrm{b}}$ & $19^{c}$ \\
\hline 30 & $11^{\mathrm{a}}$ & $13^{\mathrm{a}, \mathrm{b}}$ & $14^{\mathrm{b}, \mathrm{c}}$ & $16^{\mathrm{c}}$ \\
\hline 45 & $9^{a}$ & $12^{\mathrm{b}}$ & $12^{\mathrm{b}}$ & $14^{\mathrm{b}}$ \\
\hline 60 & $8^{\mathrm{a}}$ & $10^{\mathrm{a}, \mathrm{b}}$ & $10^{\mathrm{a}, \mathrm{b}}$ & $12^{\mathrm{b}}$ \\
\hline 75 & $7^{\mathrm{a}}$ & $8^{\mathrm{a}, \mathrm{b}}$ & $9^{\mathrm{a}, \mathrm{b}}$ & $10^{\mathrm{b}}$ \\
\hline 90 & $5^{a}$ & $6^{\mathrm{a}, \mathrm{b}}$ & $7^{\mathrm{a}, \mathrm{b}}$ & $8^{\mathrm{b}}$ \\
\hline 105 & $5^{\mathrm{a}, \mathrm{b}}$ & $4^{\mathrm{a}, \mathrm{b}}$ & $6^{\mathrm{a}, \mathrm{b}}$ & $7^{\mathrm{b}}$ \\
\hline 120 & $5^{\mathrm{a}}$ & $3^{\mathrm{a}}$ & $5^{\mathrm{a}}$ & $5^{\mathrm{a}}$ \\
\hline 135 & $2^{\mathrm{a}}$ & $2^{\mathrm{a}}$ & $3^{\mathrm{a}, \mathrm{b}}$ & $5^{b}$ \\
\hline 150 & $0^{\mathrm{a}}$ & $1^{\mathrm{a}, \mathrm{b}}$ & $1^{\mathrm{a}, \mathrm{b}}$ & $2^{\mathrm{b}}$ \\
\hline 165 & $0^{\mathrm{a}}$ & $0^{\mathrm{a}}$ & $0^{\mathrm{a}}$ & $1^{\mathrm{a}}$ \\
\hline 180 & $0^{\mathrm{a}}$ & $0^{\mathrm{a}}$ & $0^{\mathrm{a}}$ & $0^{\mathrm{a}}$ \\
\hline
\end{tabular}

TABLE 4: The viable population of $R$. leguminosarum inoculated at the rate of $30 \mathrm{~mL}$ per $175 \mathrm{~g}$ of substrate in different intervals along the storage period of vermicompost. Values are rounded of mean values of three replicates. The values with same superscript letters between columns are not significantly different at $5 \%$ level $(P<0.05)$ by Duncan's multiple-range test.

\begin{tabular}{|c|c|c|c|c|}
\hline \multirow{3}{*}{$\begin{array}{l}\text { Storage period of vermicompost } \\
\text { (after harvest, in days) }\end{array}$} & \multicolumn{4}{|c|}{ Viable population of $R$. leguminosarum $\left(\mathrm{CFU} \times 10^{7} \mathrm{~g}^{-1}\right)$} \\
\hline & \multicolumn{4}{|c|}{ Time of inoculation (vermicomposting days) } \\
\hline & 0th day & 10th day & 20th day & 30th day \\
\hline 0 & $7^{\mathrm{a}}$ & $9 \mathrm{a}, \mathrm{b}$ & $11^{\mathrm{b}}$ & $8^{\mathrm{a}}$ \\
\hline 15 & $7^{\mathrm{a}}$ & $8^{\mathrm{a}}$ & $9^{\mathrm{a}}$ & $12^{\mathrm{b}}$ \\
\hline 30 & $6^{\mathrm{a}}$ & $7^{\mathrm{a}}$ & $7^{\mathrm{a}}$ & $10^{\mathrm{b}}$ \\
\hline 45 & $6^{\mathrm{a}}$ & $6^{a}$ & $7^{\mathrm{a}}$ & $8^{\mathrm{a}}$ \\
\hline 60 & $5^{a}$ & $6^{a}$ & $7^{\mathrm{a}}$ & $7^{\mathrm{a}}$ \\
\hline 75 & $4^{\mathrm{a}}$ & $5^{\mathrm{a}, \mathrm{b}}$ & $6^{\mathrm{a}, \mathrm{b}}$ & $7^{\mathrm{b}}$ \\
\hline 90 & $4^{a}$ & $4^{\mathrm{a}}$ & $5^{\mathrm{a}}$ & $6^{\mathrm{a}}$ \\
\hline 105 & $1^{\mathrm{a}}$ & $3^{\mathrm{a}, \mathrm{b}}$ & $4^{\mathrm{b}}$ & $5^{\mathrm{b}}$ \\
\hline 120 & $0^{\mathrm{a}}$ & $2^{\mathrm{b}}$ & $3^{\mathrm{b}}$ & $3^{\mathrm{b}}$ \\
\hline 135 & $0^{\mathrm{a}}$ & $0^{\mathrm{a}}$ & $1^{\mathrm{a}}$ & $1^{\mathrm{a}}$ \\
\hline 150 & $0^{\mathrm{a}}$ & $0^{\mathrm{a}}$ & $0^{\mathrm{a}}$ & $0^{\mathrm{a}}$ \\
\hline 165 & $0^{\mathrm{a}}$ & $0^{\mathrm{a}}$ & $0^{\mathrm{a}}$ & $0^{\mathrm{a}}$ \\
\hline 180 & $0^{\mathrm{a}}$ & $0^{\mathrm{a}}$ & $0^{\mathrm{a}}$ & $0^{\mathrm{a}}$ \\
\hline
\end{tabular}

2.2. Collection of Earthworms. The earthworm, Eudrilus eugeniae (Kinberg) for the study, originally collected from culture bank of the Department of Biology, Gandhigram Rural University, Tamil Nadu, India, was mass multiplied in cowdung and used for the study.

2.3. Mass Multiplication of Biofertilizers. The cultures of Azospirillum brasilense (MTCC 4036 and Rhizobium leguminosarum (MTCC 99) were procured from microbial type culture collection (MTCC), Chandigarh and used for the study. The organisms were revealed in the suggested broth medium and subcultured in Bromothymol Blue (BTB) and
Yeast Extract Mannitol Salt Agar (YEMA) media, respectively, for A. braziliense and R. leguminosarum. A loopful of $A$. brasilense and $R$. leguminosarum was transferred respectively to $100 \mathrm{~mL}$ of, respective, selective medium and incubated. After incubation, $10 \mathrm{~mL}$ of the inoculum was transferred to $1000 \mathrm{~mL}$ of respective broth and kept in shaking incubator for mass multiplication.

2.4. Enrichment of Vermicompost with Biofertilizers. For enrichment studies, four different vermicomposting trials, each with six replicates, were carried out by preparing the vermibeds and E. eugeniae was introduced in all the vermibeds. 
TABle 5: The viable population of $R$. leguminosarum inoculated at the rate of $35 \mathrm{~mL}$ per $175 \mathrm{~g}$ of substrate in different intervals along the storage period of vermicompost. Values are rounded of mean values of three replicates. The values with same superscript letters between columns are not significantly different at $5 \%$ level $(P<0.05)$ by Duncan's multiple-range test.

\begin{tabular}{|c|c|c|c|c|}
\hline \multirow{2}{*}{$\begin{array}{l}\text { Storage period of vermicompost } \\
\text { (after harvest, in days) }\end{array}$} & \multicolumn{4}{|c|}{$\begin{array}{l}\text { Viable population of } R \text {. leguminosarum }\left(\mathrm{CFU} \times 10^{7} \mathrm{~g}^{-1}\right) \\
\text { Time of inoculation (vermicomposting days) }\end{array}$} \\
\hline & 0th day & 10th day & 20th day & 30th day \\
\hline 0 & $10^{\mathrm{a}}$ & $11^{\mathrm{a}}$ & $12^{\mathrm{a}}$ & $10^{\mathrm{a}}$ \\
\hline 15 & $9^{a}$ & $10^{\mathrm{a}, \mathrm{b}}$ & $11^{\mathrm{a}, \mathrm{b}}$ & $13^{\mathrm{b}}$ \\
\hline 30 & $9^{\mathrm{a}}$ & $9^{a}$ & $10^{\mathrm{a}, \mathrm{b}}$ & $12^{\mathrm{b}}$ \\
\hline 45 & $8^{\mathrm{a}}$ & $9^{a}$ & $9^{a}$ & $10^{\mathrm{a}}$ \\
\hline 60 & $7^{\mathrm{a}}$ & $8^{\mathrm{a}}$ & $9^{a}$ & $8^{a}$ \\
\hline 75 & $6^{\mathrm{a}}$ & $7^{\mathrm{a}}$ & $8^{\mathrm{a}}$ & $8^{\mathrm{a}}$ \\
\hline 90 & $5^{\mathrm{a}}$ & $6^{\mathrm{a}}$ & $7^{\mathrm{a}}$ & $7^{\mathrm{a}}$ \\
\hline 105 & $3^{\mathrm{a}}$ & $6^{\mathrm{b}}$ & $6^{\mathrm{b}}$ & $7^{\mathrm{b}}$ \\
\hline 120 & $1^{\mathrm{a}}$ & $3^{\mathrm{a}}$ & $6^{\mathrm{b}}$ & $6^{\mathrm{b}}$ \\
\hline 135 & 0 & 1 & 3 & 5 \\
\hline 150 & $0^{\mathrm{a}}$ & $0^{\mathrm{a}}$ & $1^{\mathrm{a}, \mathrm{b}}$ & $2^{\mathrm{b}}$ \\
\hline 165 & $0^{\mathrm{a}}$ & $0^{\mathrm{a}}$ & $0^{\mathrm{a}}$ & $1^{\mathrm{a}}$ \\
\hline 180 & $0^{\mathrm{a}}$ & $0^{\mathrm{a}}$ & $0^{\mathrm{a}}$ & $0^{\mathrm{a}}$ \\
\hline
\end{tabular}

TABLE 6: The viable population of $R$. leguminosarum inoculated at the rate of $40 \mathrm{~mL}$ per $175 \mathrm{~g}$ of substrate in different intervals along the storage period of vermicompost. Values are rounded of mean values of three replicates. The values with same superscript letters between columns are not significantly different at $5 \%$ level $(P<0.05)$ by Duncan's multiple-range test.

\begin{tabular}{|c|c|c|c|c|}
\hline \multirow{2}{*}{$\begin{array}{l}\text { Storage period of vermicompost } \\
\text { (after harvest, in days) }\end{array}$} & \multicolumn{4}{|c|}{$\begin{array}{l}\text { Viable population of } R \text {. leguminosarum }\left(\mathrm{CFU} \times 10^{7} \mathrm{~g}^{-1}\right) \\
\text { Time of inoculation (vermicomposting days) }\end{array}$} \\
\hline & 0th day & 10th day & 20th day & 30th day \\
\hline 0 & $10^{\mathrm{a}}$ & $12^{\mathrm{a}, \mathrm{b}}$ & $13^{\mathrm{b}}$ & $10^{\mathrm{a}}$ \\
\hline 15 & $10^{\mathrm{a}}$ & $10^{\mathrm{a}}$ & $11^{\mathrm{a}}$ & $14^{\mathrm{b}}$ \\
\hline 30 & $9^{a}$ & $10^{\mathrm{a}}$ & $10^{\mathrm{a}}$ & $14^{\mathrm{b}}$ \\
\hline 45 & $8^{\mathrm{a}}$ & $9^{\mathrm{a}}$ & $10^{\mathrm{a}, \mathrm{b}}$ & $12^{\mathrm{b}}$ \\
\hline 60 & $7^{\mathrm{a}}$ & $7^{\mathrm{a}}$ & $9^{\mathrm{a}, \mathrm{b}}$ & $10^{\mathrm{b}}$ \\
\hline 75 & $6^{\mathrm{a}}$ & $7^{\mathrm{a}}$ & $8^{\mathrm{a}}$ & $8^{a}$ \\
\hline 90 & $4^{\mathrm{a}}$ & $6^{\mathrm{a}, \mathrm{b}}$ & $7^{\mathrm{b}}$ & $7^{b}$ \\
\hline 105 & $4^{\mathrm{a}}$ & $5^{\mathrm{a}, \mathrm{b}}$ & $6^{\mathrm{a}, \mathrm{b}}$ & $7^{b}$ \\
\hline 120 & $1^{\mathrm{a}}$ & $3^{\mathrm{a}, \mathrm{b}}$ & $4^{\mathrm{b}}$ & $5^{\mathrm{b}}$ \\
\hline 135 & $0^{\mathrm{a}}$ & $0^{\mathrm{a}}$ & $1^{\mathrm{a}, \mathrm{b}}$ & $3^{b}$ \\
\hline 150 & $0^{\mathrm{a}}$ & $0^{\mathrm{a}}$ & $0^{\mathrm{a}}$ & $1^{\mathrm{a}}$ \\
\hline 165 & $0^{\mathrm{a}}$ & $0^{\mathrm{a}}$ & $0^{\mathrm{a}}$ & $0^{\mathrm{a}}$ \\
\hline 180 & $0^{\mathrm{a}}$ & $0^{\mathrm{a}}$ & $0^{\mathrm{a}}$ & $0^{\mathrm{a}}$ \\
\hline
\end{tabular}

The vermicompost was collected from all the vermibeds after 40 days. The mass multiplied biofertilizer organisms at the rate of 30,35 , and $40 \mathrm{~mL}$ per $175 \mathrm{~g}$ of vermibed substrates were added to each of the experiments, T1, T2, T3, and T4 on the 0th, 10th, 20th and 30th day, respectively, to find out the optimum inoculum level and time of inoculation that results in the maintenance of $1 \times 10^{7}$ viable cells per gram of vermicompost during storage.

2.5. Statistical Analyses. Data were subjected for analysis of variance (ANOVA) followed by Duncan's multiple-range test to differentiate the significant difference between different treatments at the probability level of $P<0.05$ using SPSS computer software for Windows (version 9.05). The relation between viable cell counts in different carrier materials and incubation days were carried out using Microcal Origin Computer Software (Version 6.1) and correlation coefficient $(r)$ was calculated.

\section{Results and Discussion}

3.1. Enrichment of Vermicompost with A. brasilense and R. leguminosarum. Earthworm activity is closely associated with microbial activity. There exists a mutualistic association 


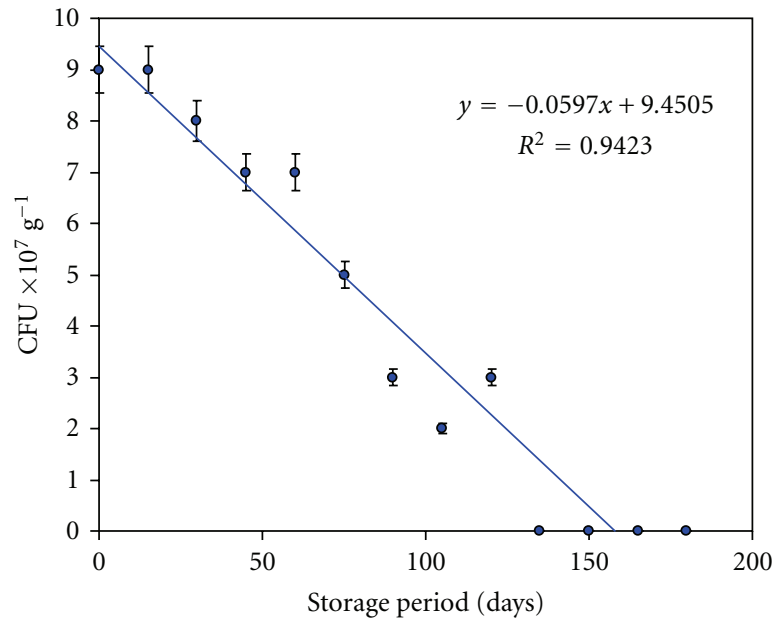

(a)

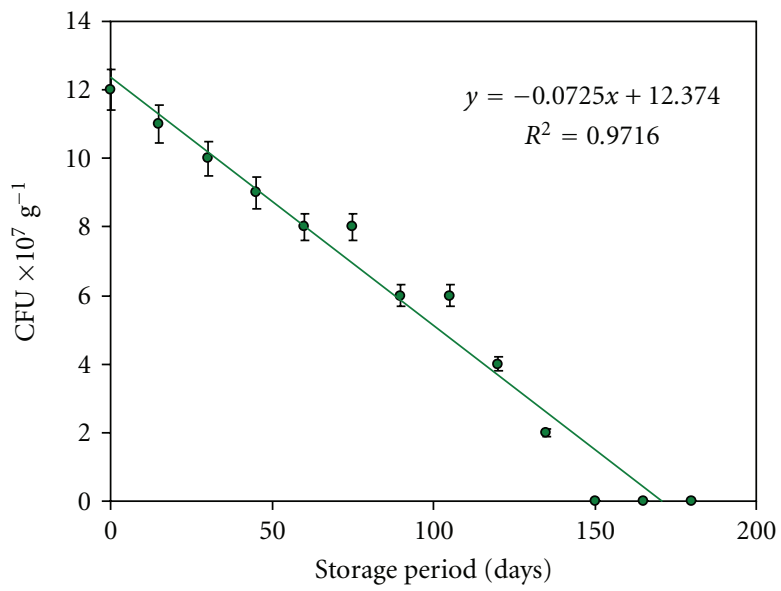

(c)

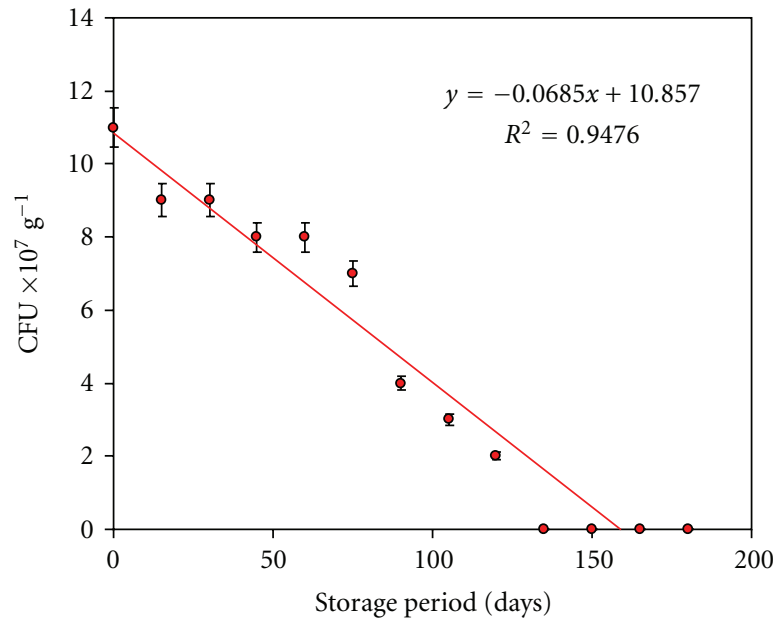

(b)

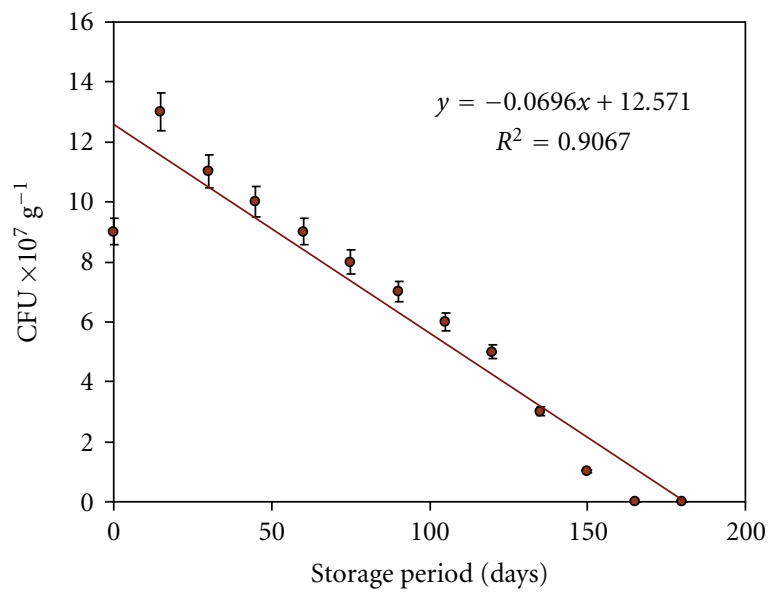

(d)

Figure 1: The change of $A$. brasilense population in the vermicompost (at $30 \mathrm{~mL}$ per $175 \mathrm{~g}$ of substrate) during storage period (180 days). Error bars indicate \pm SD; Time of inoculation of A. brasilense during vermicomposting: (a) 0th day, (b) 10th day, (c) 20th day, and (d) 30th day.

TABLE 7: The total microbial population change in A. brasilense inoculated vermicompost during storage period. Values are rounded of mean values of three replicates.

\begin{tabular}{|c|c|c|c|c|c|c|c|c|c|c|c|c|}
\hline \multirow[t]{2}{*}{$\begin{array}{l}\text { Storage period of vermicompost } \\
\text { (after harvest, in days) }\end{array}$} & \multicolumn{3}{|c|}{$30 \mathrm{~mL}$} & To & $\begin{array}{l}\text { micr } \\
\text { the of } \\
\text { of inc }\end{array}$ & $\begin{array}{l}\text { al pop } \\
\text { oculu } \\
\text { lation }\end{array}$ & $\begin{array}{l}\text { tion } \\
\text { er } 175 \\
\text { L } \\
\text { rmico }\end{array}$ & $\begin{array}{l}\times 10 \\
\text { abstra }\end{array}$ & & \multicolumn{2}{|c|}{$40 \mathrm{~mL}$} & \\
\hline & $0 \mathrm{~d}$ & $10 \mathrm{~d}$ & $20 \mathrm{~d}$ & $30 \mathrm{~d}$ & $0 \mathrm{~d}$ & $10 \mathrm{~d}$ & $20 \mathrm{~d}$ & $30 \mathrm{~d}$ & od & $10 \mathrm{~d}$ & $20 \mathrm{~d}$ & $30 d$ \\
\hline 0 & 16 & 19 & 20 & 17 & 16 & 17 & 18 & 16 & 21 & 22 & 26 & 20 \\
\hline 15 & 16 & 16 & 17 & 23 & 14 & 15 & 15 & 24 & 18 & 20 & 21 & 29 \\
\hline 30 & 15 & 15 & 16 & 20 & 12 & 13 & 14 & 18 & 16 & 18 & 21 & 26 \\
\hline 45 & 12 & 14 & 14 & 18 & 10 & 11 & 12 & 16 & 13 & 16 & 17 & 21 \\
\hline 60 & 12 & 13 & 13 & 16 & 10 & 10 & 10 & 14 & 11 & 13 & 14 & 16 \\
\hline 75 & 10 & 10 & 12 & 13 & 6 & 7 & 8 & 11 & 8 & 10 & 11 & 13 \\
\hline 90 & 7 & 7 & 10 & 11 & 4 & 5 & 6 & 9 & 5 & 7 & 9 & 11 \\
\hline 105 & 3 & 5 & 9 & 9 & 1 & 3 & 4 & 7 & 3 & 4 & 7 & 9 \\
\hline 120 & 3 & 3 & 6 & 8 & 0 & 1 & 2 & 5 & 0 & 2 & 4 & 5 \\
\hline 135 & 0 & 1 & 3 & 5 & 0 & 0 & 1 & 3 & 0 & 0 & 1 & 2 \\
\hline 150 & 0 & 0 & 1 & 2 & 0 & 0 & 0 & 1 & 0 & 0 & 0 & 0 \\
\hline 165 & 0 & 0 & 0 & 0 & 0 & 0 & 0 & 0 & 0 & 0 & 0 & 0 \\
\hline 180 & 0 & 0 & 0 & 0 & 0 & 0 & 0 & 0 & 0 & 0 & 0 & 0 \\
\hline
\end{tabular}




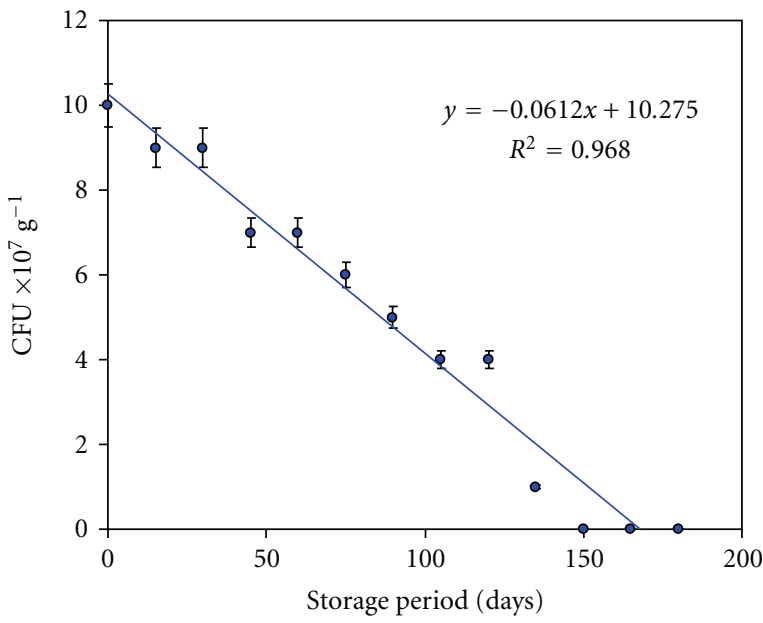

(a)

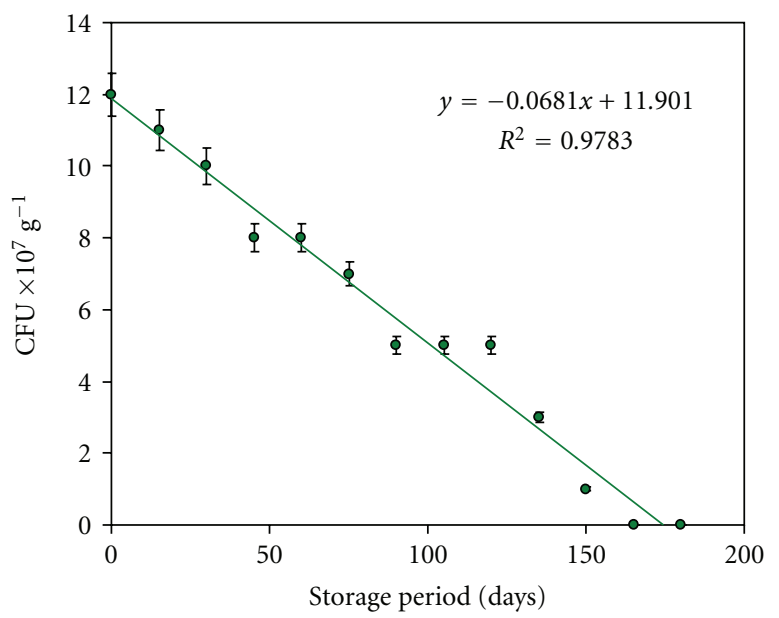

(c)

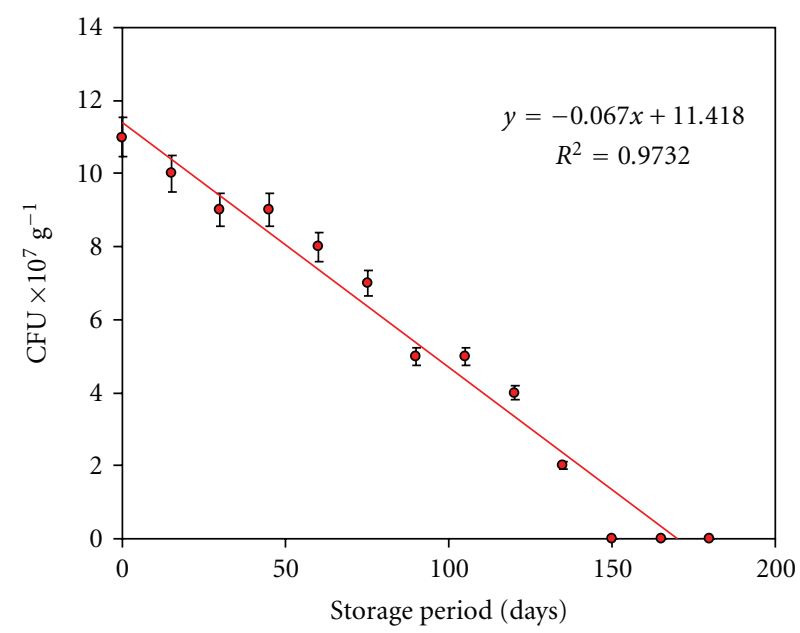

(b)

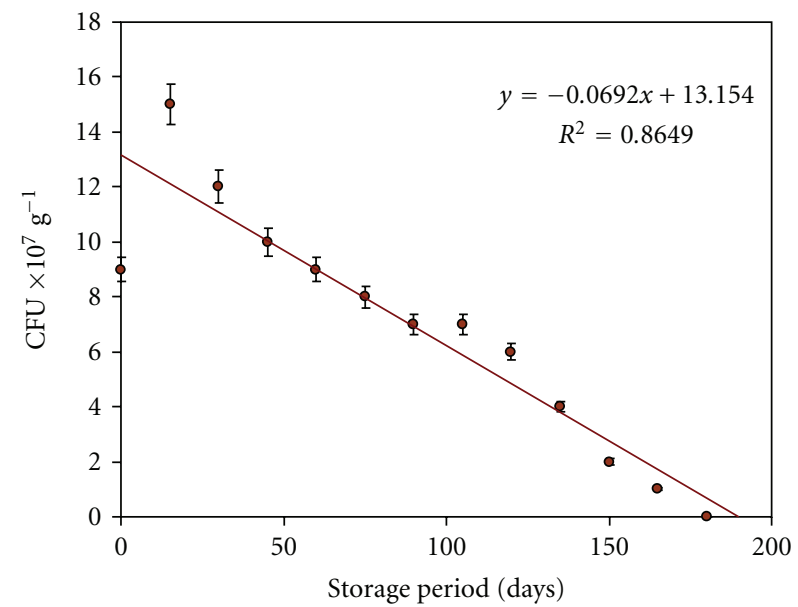

(d)

FIgURE 2: The change of A. brasilense population in the vermicompost ( $35 \mathrm{~mL}$ per $175 \mathrm{~g}$ of substrate) during storage period (180 days). Error bars indicate \pm SD; time of inoculation of A. brasilense during vermicomposting: (a) 0th day, (b) 10th day, (c) 20th day, and (d) 30th day.

between earthworm and microorganisms in deriving nutrients from harder materials like cellulose and hemicellulose [16]. The enrichment of vermicompost with nutrients and microorganisms using different organic and inorganic materials and microbial inoculants is now popularizing, due to the advantage of using the "enriched vermicompost" [17-20]. But these studies have not described the standardized protocol for enriching vermicompost with microbial inoculants such as biofertilizers.

The enrichment of vermicompost was done in the present study by inoculating the biofertilizer inoculants, $A$. brasilense and $R$. leguminosarum, at the rate of 30,35 , and $40 \mathrm{~mL} / 175 \mathrm{~g}$ of substrate. This was done to find out the optimum level of inoculum required for the maintenance of $1 \times 10^{7}$ viable cells in the vermicompost. The inoculation was done on the 0th, 10th, 20th and 30th days of vermicomposting to assess whether the time of inoculation had any effect on survival rate of biofertilizer inoculants during storage. At the same time, the survival rates of each inoculant were correlated with total microbial population in the vermicompost to study the influence of other microbial groups on biofertilizer inoculants. Microbial inoculation on 0th, 10th, 20th, and 30th days showed decrease in the viable population of $A$. brasilense and $R$. leguminosarum inoculated at the rate of 30,35 , and $40 \mathrm{~mL} / 175 \mathrm{~g}$ of substrate, towards the progression of storage period of vermicompost, uniformly. The change of $A$. brasilense and R. leguminosarum in the vermicompost (at 30,35 , and $40 \mathrm{~mL} / 175 \mathrm{~g}$ substrate) with reference to the storage period (180 days) showed a highly significant negative correlation $(P<0.001)$. In all the treatments, the viable population of $A$. brasilense and R. leguminosarum at the rates of 30,35 , and $40 \mathrm{~mL} / 175 \mathrm{~g}$ substrate from 0th day (after harvest) onwards showed statistically significant decline with that of storage period of vermicompost. This trend was observed uniformly for all the four microbial inoculants, ionoculated on the 0th, 10th, 20th, and 30th days of vermicomposting.

The viable population of $A$. brasilense inoculated at the rate of $30 \mathrm{~mL} / 175 \mathrm{~g}$ of substrate on the 30th day of vermicomposting showed $11,9,7,5$, and $1 \times 10^{7} \mathrm{~g}^{-1} \mathrm{CFU}$ during 


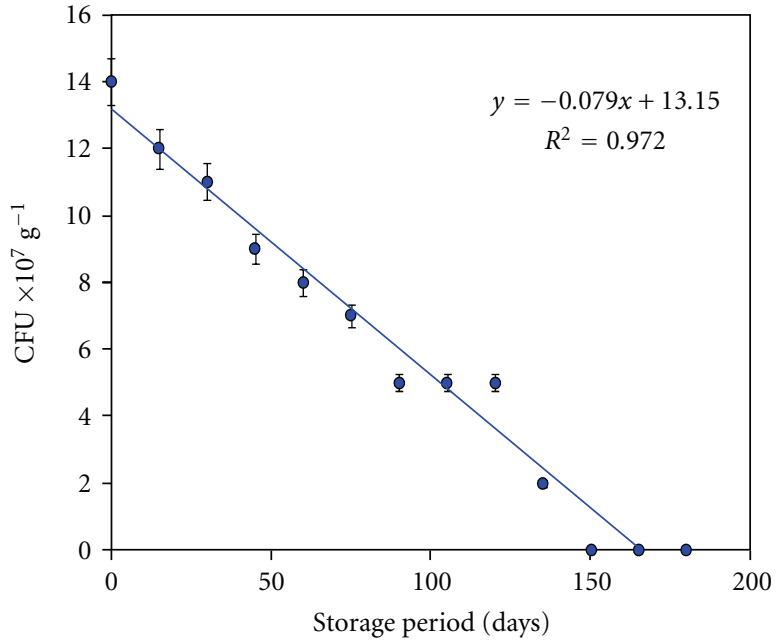

(a)

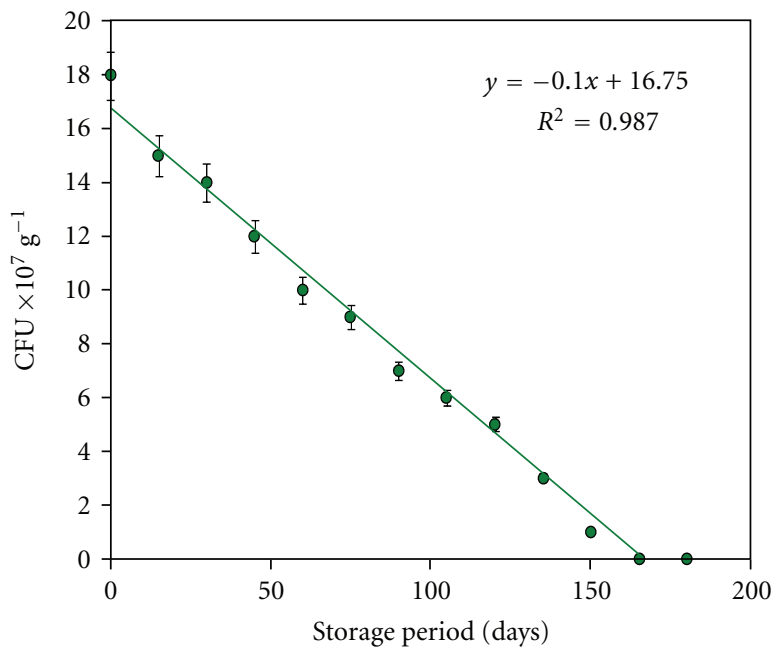

(c)

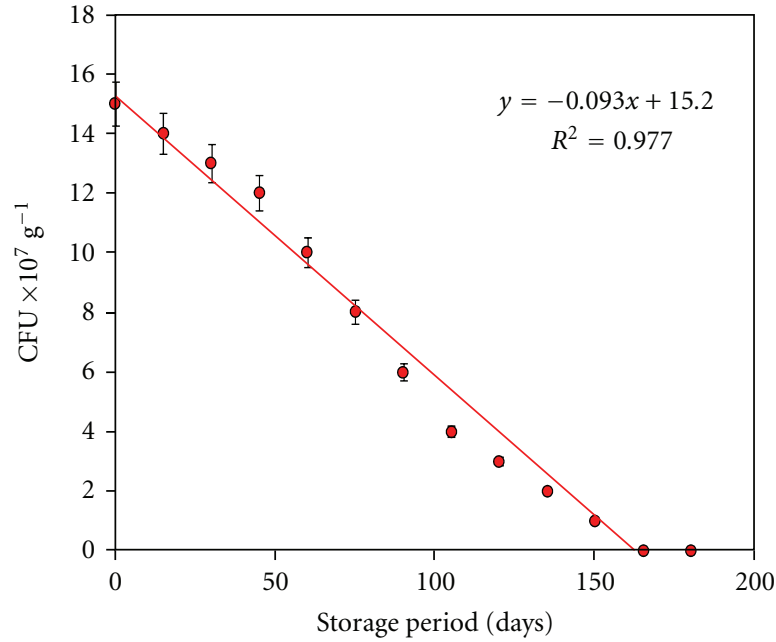

(b)

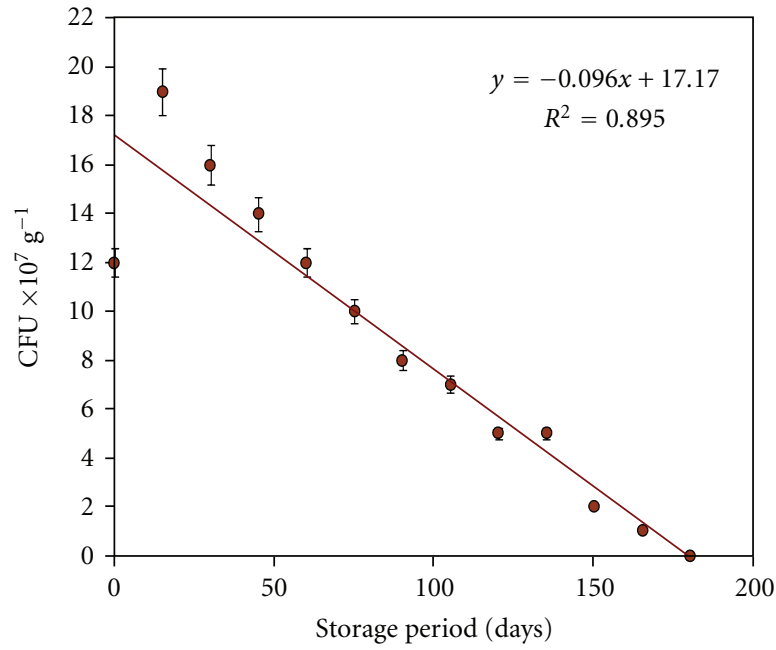

(d)

FIgURE 3: The change of $A$. brasilense population in the vermicompost (at $40 \mathrm{~mL}$ per $175 \mathrm{~g}$ of substrate) during storage period (180 days). Error bars indicate \pm SD; time of inoculation of A. brasilense during vermicomposting: (a) 0th day, (b) 10th day, (c) 20th day and (d) 30th day.

the 30th, 60th, 90th, 120th, and 150th days, respectively, which was negatively significant at $P<0.001(y=$ $-0.0696 x+12.71, R^{2}=0.9067$ ) (Table 1; Figure 1). Similar results were obtained for 35 and $40 \mathrm{~mL} / 175 \mathrm{~g}$ of substrate inoculation (Tables 2 and 3; Figures 2 and 3 ). The viable population of $R$. leguminosarum inoculated at the rates of 30 , 35 , and $40 \mathrm{~mL} / 175 \mathrm{~g}$ substrate in different intervals showed decrease in viable population during the storage of vermicompost (Tables 4, 5, and 6). The decrease of viable population upon storage of vermicompost which received $R$. leguminosarum inoculants at different intervals was negatively correlated (Figures 4, 5, and 6). The population of $R$. leguminosarum at the rate of $40 \mathrm{~mL} / 175 \mathrm{~g}$ substrate inoculated on the 0th day and 10th day of vermicomposting showed 1 and $3 \times 10^{7} \mathrm{~g}^{-1} \mathrm{CFU}$ on the 120th day of storage after harvest. There after no viable cells were observed up to 180 days. On the 20th and 30th days of inoculation, the survival of $R$. leguminosarum was observed up to the 135th and 150th day, and the subsequent observations showed no viable population up to 180 days.

The enrichment of vermicompost with the addition of nutrient rich substrates was demonstrated by Daniel et al. [21], where their results reveal that the leaves of Gliricidia sepium and Leucaena leucocephala can be converted into microbial- and nutrient-rich vermicompost using E. fetida. Hashemimajd and Golchin [19] studied the effect of ironenriched vermicompost on growth and nutrition of tomato and reported that total and available forms of iron in ironenriched vermicomposts as well as in tomato tissues increased by an increase in the proportion of iron refuse in vermicompost. Some authors tried microbial inoculants for hastening the process of vermicomposting or for enriching the vermicompost. The inoculation of microbial consortia like "jeevamrutha" and cow dung together with organic substrates significantly enhances the microbial density throughout the process of decomposition during vermicomposting 


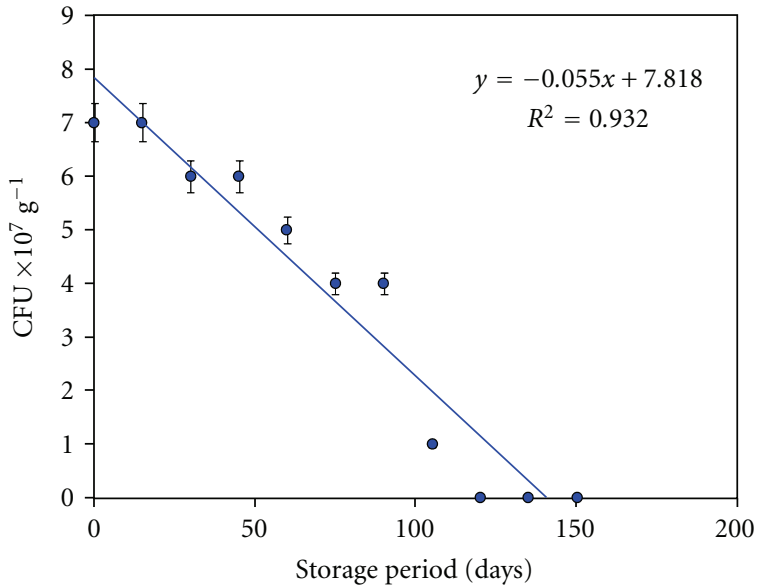

(a)

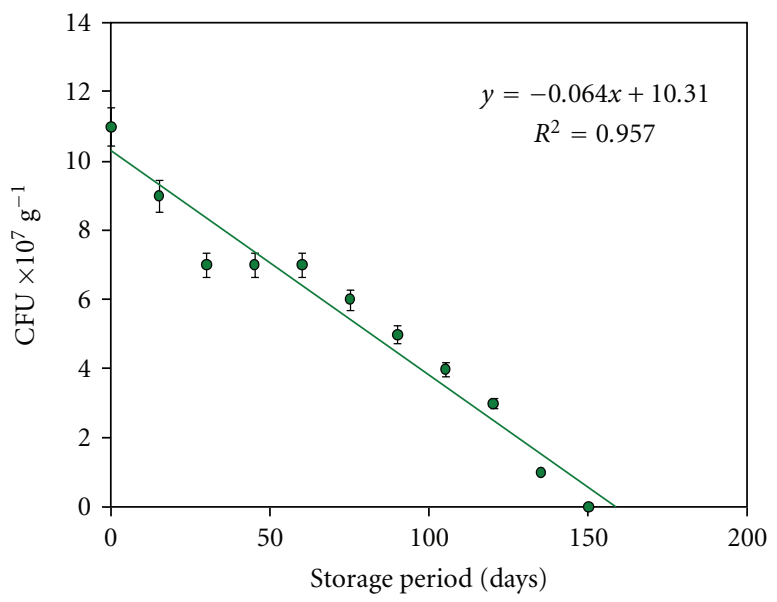

(c)

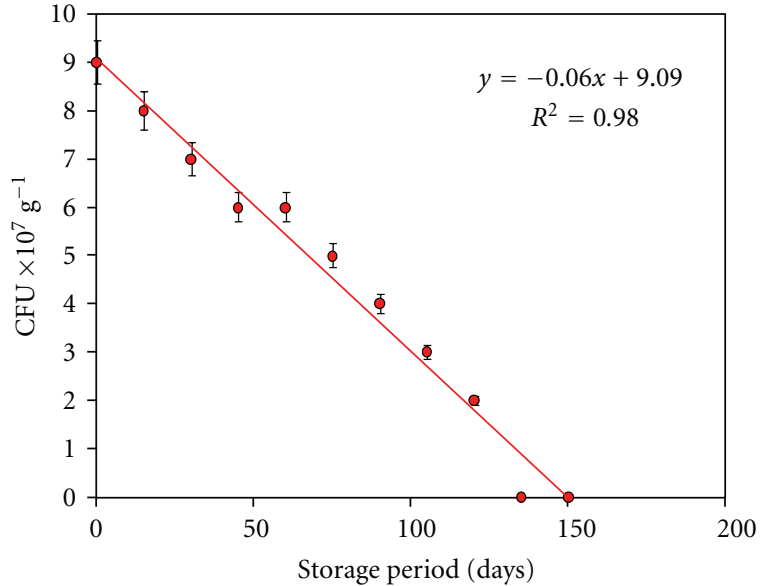

(b)

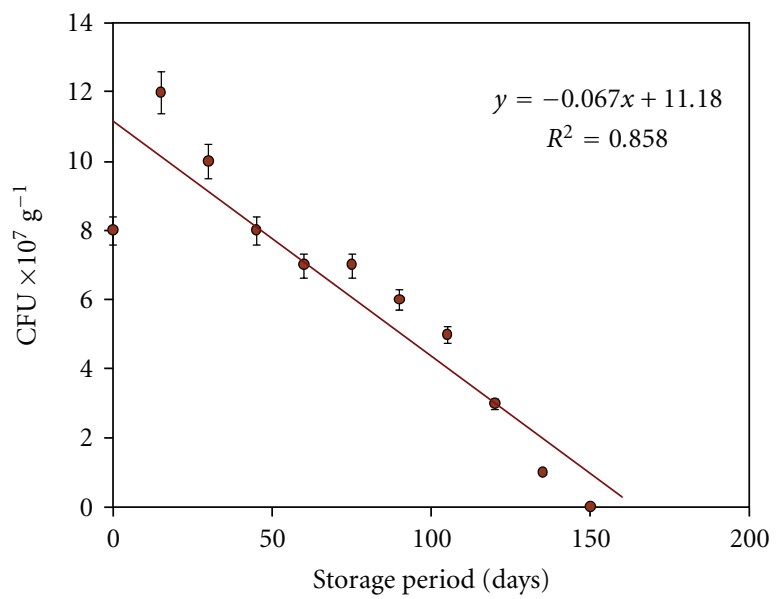

(d)

FIgURE 4: The change of R. leguminosarum population in the vermicompost (at $30 \mathrm{~mL}$ per $175 \mathrm{~g}$ of substrate) during storage period (180 days). Error bars indicate \pm SD; time of inoculation of $R$. leguminosarum during vermicomposting: (a) 0th day, (b) 10th day, (c) 20th day, and (d) 30th day.

[22]. The inoculation of consortium of microorganisms Aspergillus niger, P. sajor-caju, Azotobacter chroococcum, Trichoderma harzianum not only accelerated vermicomposting of crop residues and farm yard manure but also enriched the quality of product [17]. During the incubation period the inoculated bacterial strains proliferated rapidly, fixed nitrogen, solubilised, and added native phosphate [23].

Pressmud alone and in combination with other byproducts of sugar processing industries was pre-decomposed for 30 days by inoculation with combination of Pleurotus sajorcaju, Trichoderma viridae, Aspergillus niger, and Pseudomonas striatum, followed by vermicomposting for 40 days with the native earthworm, Drawida willsi. The combination of both treatments reduced the overall time required for composting to 20 days and accelerated the degradation process, thereby producing a nutrient-enriched compost product [20]. The study conducted by Padmavathiamma et al. [24] reported that the enrichment generally had a significant effect on the nutrient contents, especially for $\mathrm{N}, \mathrm{P}, \mathrm{K}, \mathrm{Mg}$, and Mn. Eudrilus compost, when treated with Azospirillum and
P-solubilising organisms, gave an $\mathrm{N}$-content of $2.08 \%$ which was significantly higher than the $\mathrm{N}$-content of uninoculated Eudrilus compost (1.8\%). The nitrogen was enriched appreciably by Azospirillum. The enrichment increased progressively when Azospirillum inoculation was supplemented with phosphate solubilising culture, a beneficial additive to obtain good quality compost, rich in $\mathrm{N}$ [25]. An increase in N-content due to microbial inoculation was reported by Rasal et al. [26]. The P-contents were significantly higher when inoculated with Azospirillum and P-solubilising organisms (1.76\%) than in uninoculated compost $(0.72 \%)$. The mechanisms of conversion of insoluble $\mathrm{P}$ by $\mathrm{P}$-solubilising organisms to available forms include altering the solubility of inorganic compounds to the ultimate soluble form by production of acids and $\mathrm{H}_{2} \mathrm{~S}$ under aerobic and anaerobic conditions and by mineralizing organic compounds, with the release of inorganic phosphate [26].

Kumar and Shweta [25] studied the enhancement of wood waste decomposition by microbial inoculation prior to vermicomposting. The timber wastes which were inoculated 


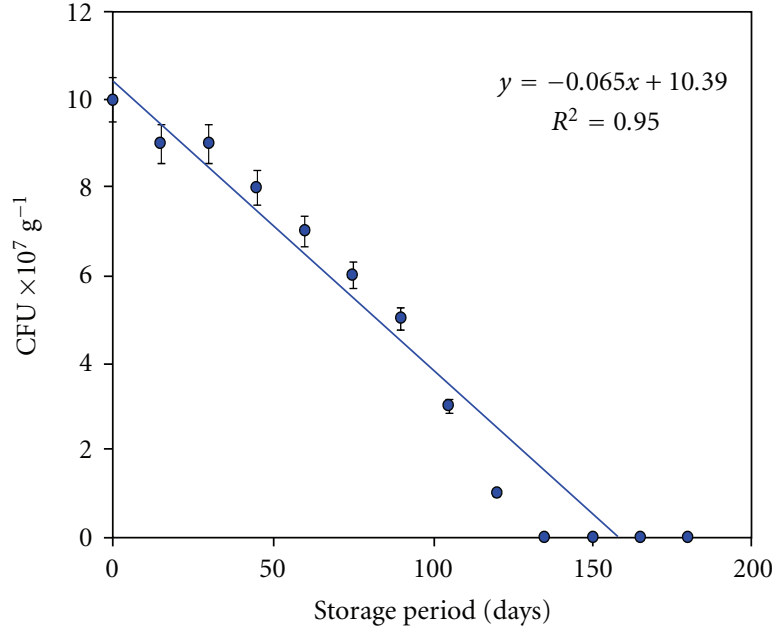

(a)

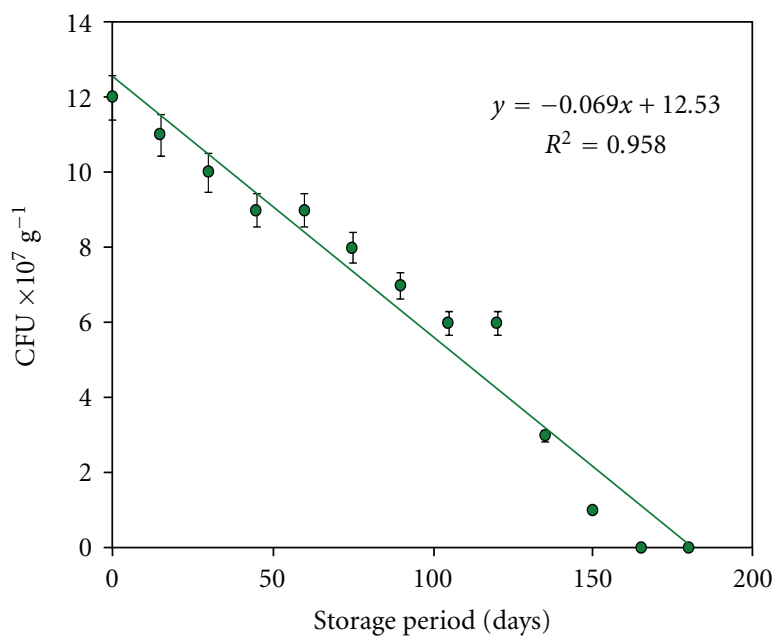

(c)

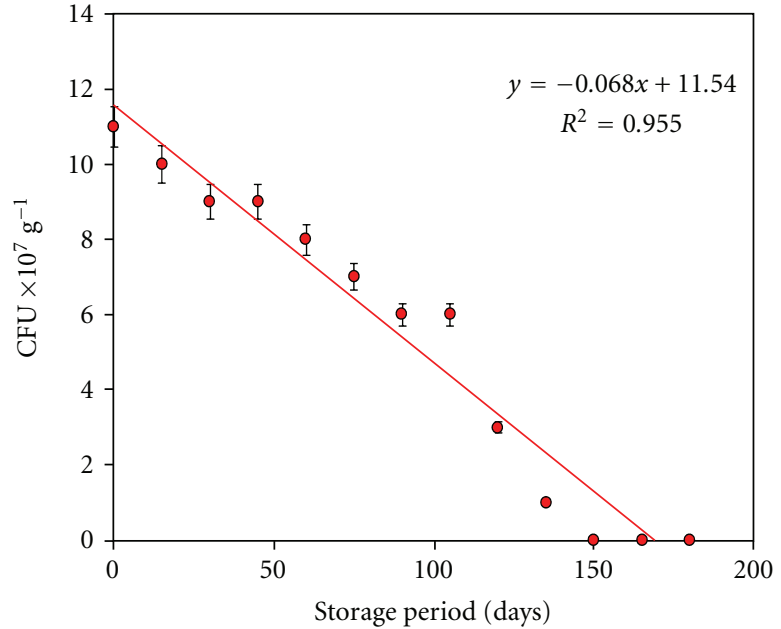

(b)

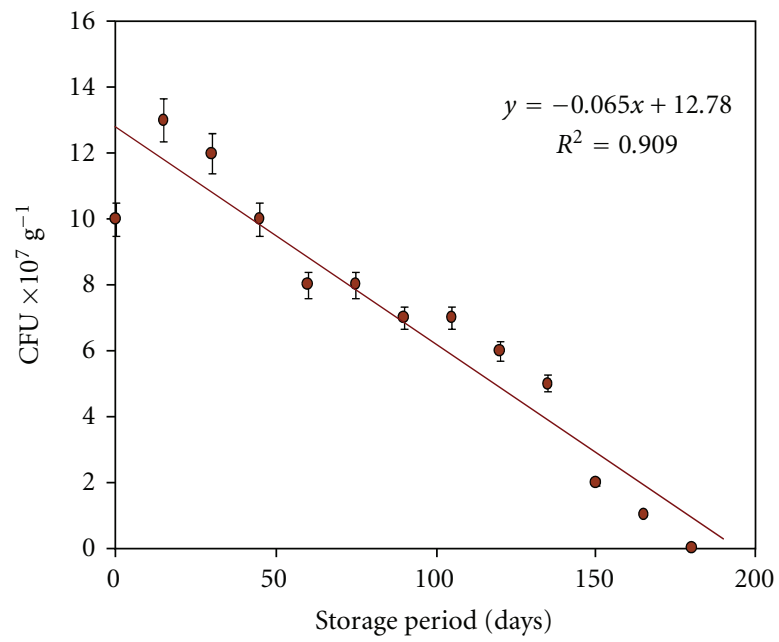

(d)

Figure 5: The change of $R$. leguminosarum population in the vermicompost (at $35 \mathrm{~mL}$ per $175 \mathrm{~g}$ of substrate) during storage period (180 days). Error bars indicate \pm SD; time of inoculation of $R$. leguminosarum during vermicomposting: (a) 0th day, (b) 10th day, (c) 20th day, and (d) 30th day.

with different combinations of the fungi Phanerochaete chrysosporium, Trichoderma reesei, Aspergillus niger, and the bacteria Azotobacter chroococcum (MTCC 3853) and Bacillus cereus (MTCC 4079 ) and incubated at $28-30^{\circ} \mathrm{C}$ in a mechanical composter. The inoculation enhanced the degradation of timber wastes, increased total nitrogen, and improved the quality and enhanced production of vermicompost generated with the native earthworm Drawida willsi Michelsen. Their study showed that microbial predecomposition of timber wastes to produce quality vermicompost is a feasible technology. However, the above studies were focused on either the enhancement of vermicomposting process or the nutrients. These studies have not described the standardization of amount of inoculum and time of inoculation for the maintenance of $1 \times 10^{7} \mathrm{~g}^{-1}$ viable population of A. brasilense and $R$. leguminosarum and their survival during storage in comparison with the total microbial population. From the results of this study, it is concluded that the biofertilizer inoculants, $A$. brasilense and $R$. leguminosarum, at the rate $35 \mathrm{~mL} / 175 \mathrm{~g}$ substrate on the 30th day of vermicomposting are the optimum inoculation level and time for the maintenance of $1 \times 10^{7}$ viable cells in the vermicompost is the maximum number of days during storage (Figure 7). The study also reveals that the microbial inoculants inoculated at the later stage of vermicomposting survive for long period.

\subsection{Total Microbial Population and the Microbial Inoculants.} In the present study, total microbial population in A. brasilense and $R$. leguminosarum inoculated vermicompost was high during the initial phases of storage and then total microbial population declined towards the end (Tables 7 and 8). No viable population of total microorganisms in $10^{7}$ dilution on the135th, 150th, 265th and 165th days of storage was observed, respectively, in the 0th, 10th, 20th, and 30th days inoculation of $A$. brasilense at the rate of $30 \mathrm{~mL} / 175 \mathrm{~g}$ substrate. The vermicompost inoculated on the 20th day of 


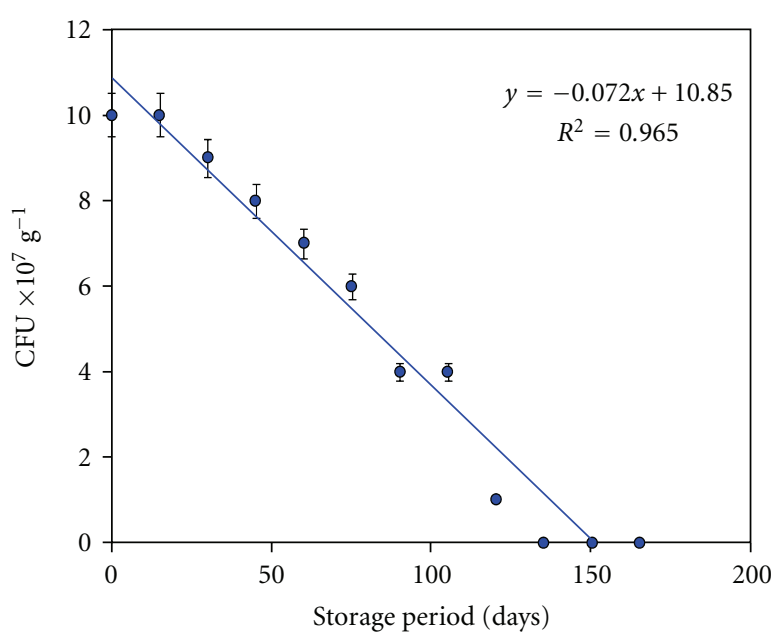

(a)

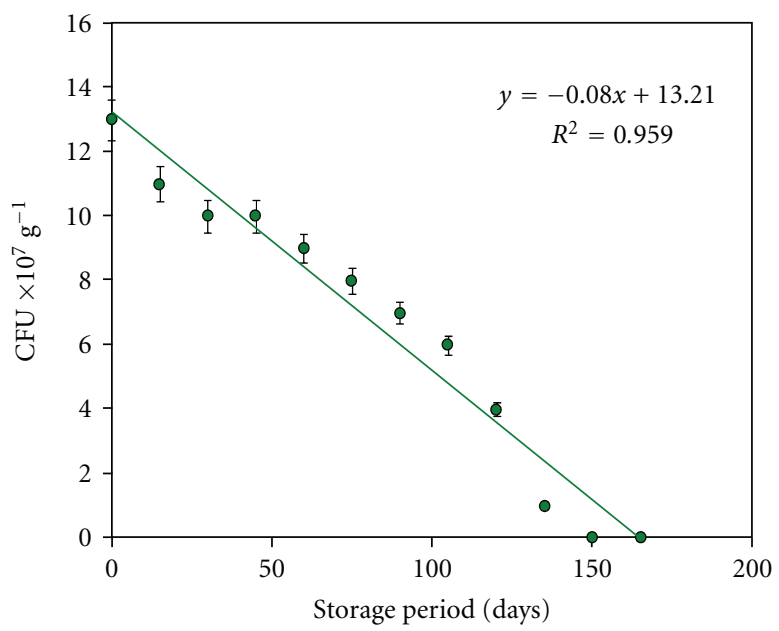

(c)

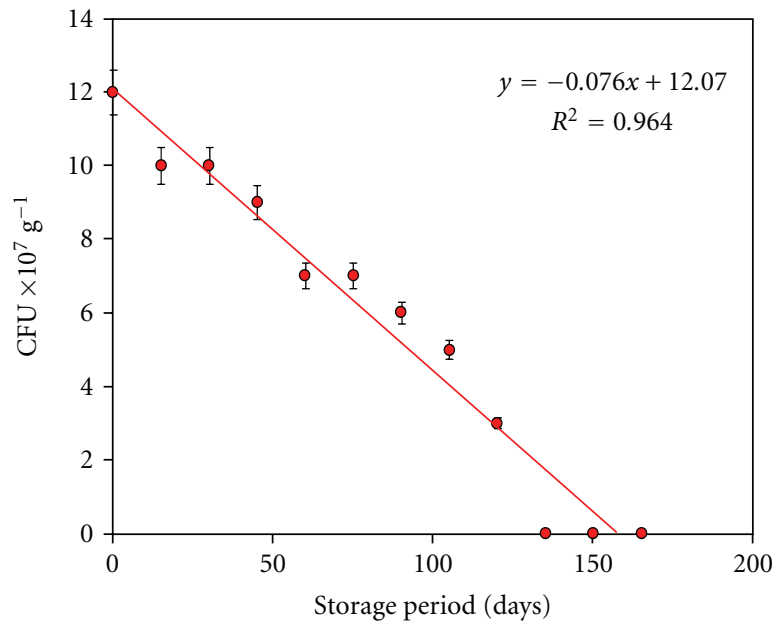

(b)

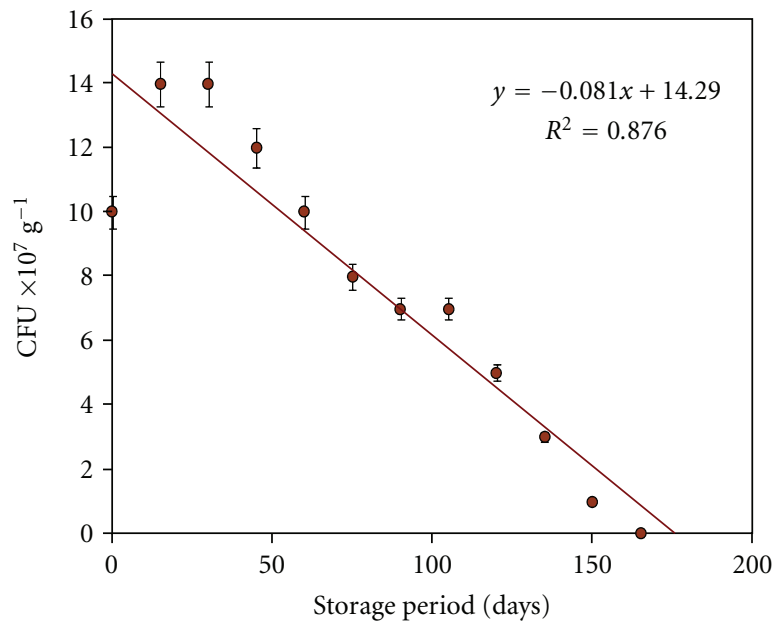

(d)

Figure 6: The change of $R$. leguminosarum population in the vermicompost (at $40 \mathrm{~mL}$ per $175 \mathrm{~g}$ of substrate) during storage period (180 days). Error bars indicate \pm SD; time of inoculation of $R$. leguminosarum during vermicomposting: (a) 0th day, (b) 10th day, (c) 20th day, and (d) 30th day.

vermicomposting with $A$. brasilense at the rate of $35 \mathrm{~mL} / 175 \mathrm{~g}$ of substrate showed $15,12,8,4,1$, and $0 \times 10^{7} \mathrm{CFU} \mathrm{g}^{-1}$ population of total microorganisms, respectively, during 15th, 45th, 75th, 105th, 135th, and 165th days of storage. Similar trend of results was obtained for R. leguminosarum inoculated vermicompost suggesting that the overall maintenance of total microbial population in vermicompost is similar in the vermicomposts with any microbial inoculant. The change of total microbial population in A. brasilense and $R$. leguminosarum inoculated vermicompost (at 30,35 , and $40 \mathrm{~mL} /$ $175 \mathrm{~g}$ substrate) as a function of storage period (180 days) showed negative correlation in all the treatments received microbial inoculants during the 0th, 10th, 20th, and 30th days of vermicomposting. The vermicompost inoculated with $A$. brasilense on 0 th day of vermicomposting showed significant $(P<0.001)$ negative correlation with a correlation coefficient $(r):-0.9794(y=-0.1166 x+17.449)$. Similar results were recorded for 10th day inoculation: $r=-0.9898$, $y=-0.1242 x+18.833$; for the 20th day inoculation: $r=-0.9913, y=-0.1186 x+19.872$; for the 30th day inoculation: $r=-0.9605, y=-0.129 x+22.487$. For $R$. leguminosarum also, comparatively, similar results were observed (data not shown).

The correlation of total microbial population with the individual microbial inoculants, $A$. brasilense and $R$. leguminosarum in respective vermicompost during storage period, showed significant positive correlation, that is, the increase/ decrease of individual inoculants and total microbial population were parallel (Table 9). The viable population of $R$. leguminosarum inoculated $(40 \mathrm{~mL} / 175 \mathrm{~g})$ on the 0th day of vermicomposting was significantly correlated with total microbial population recorded during storage $(r=0.960573$; $y=0.5456 x+1.3712 ; P<0.001)$. Similar positive correlation was recorded for different time of inoculation and with different inoculum level (data not shown). These results clearly show that the population of microbial inoculants and 
TABLE 8: The total microbial population change in R. leguminosarum inoculated vermicompost during storage period. Values are rounded of mean values of three replicates.

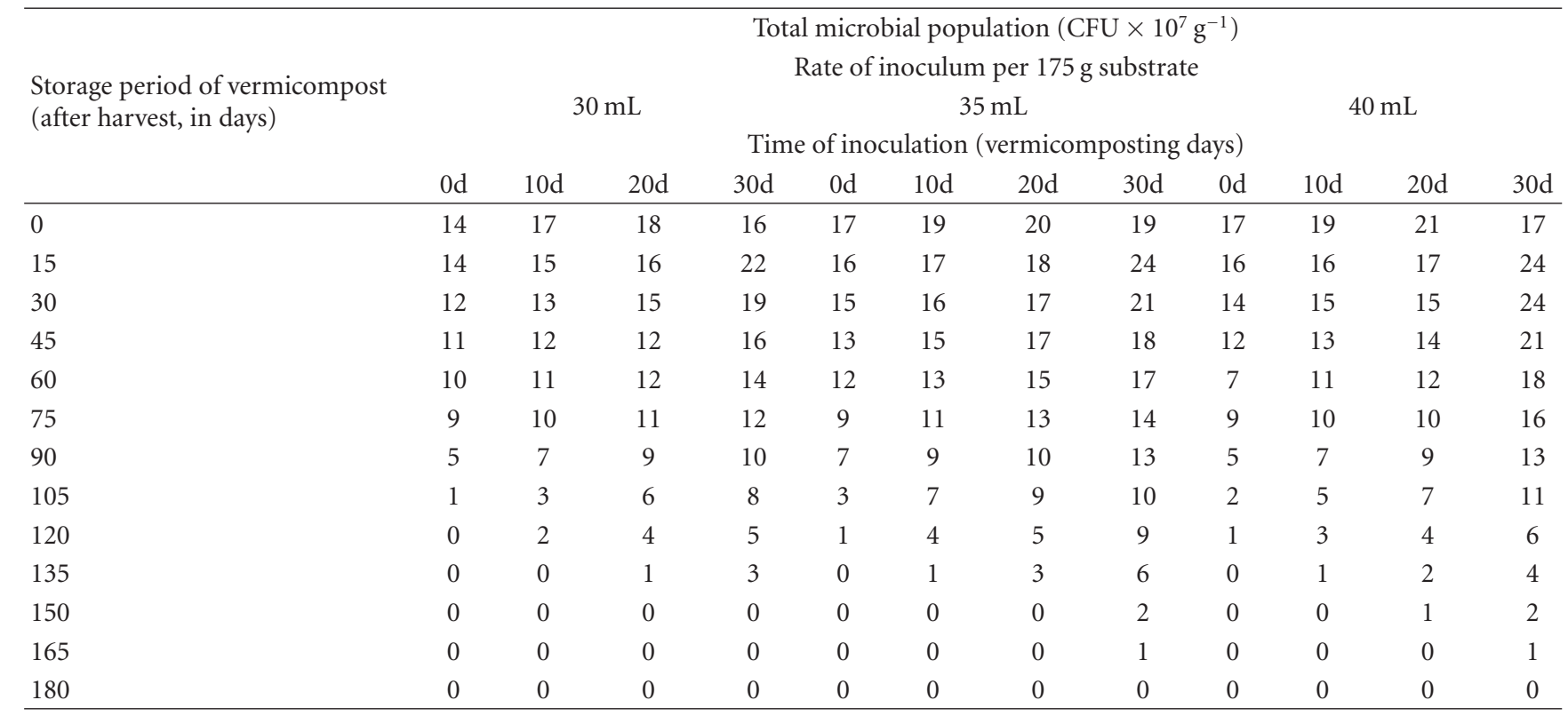

TABLE 9: Correlation of population dynamics between total microflora and A. brasilense and R. leguminosarum during storage of enriched vermicompost (180 days).

\begin{tabular}{|c|c|c|c|c|c|}
\hline \multirow{2}{*}{\multicolumn{2}{|c|}{$\begin{array}{l}\text { Inoculum } \\
\text { (mL/175 g) }\end{array}$}} & \multicolumn{4}{|c|}{ Time of inoculation (days of vermicomposting) } \\
\hline & & 0 & 10 & 20 & 30 \\
\hline \multicolumn{6}{|c|}{ A. brasilense versus total microflora } \\
\hline \multirow[t]{2}{*}{30} & $\mathrm{Eq}$ & $y=0.5311 x+0.3074$ & $y=0.5898 x+0.0248$ & $y=0.6109 x+0.2566$ & $y=0.5089 x+0.9782$ \\
\hline & $r$ & 0.9827 & 0.9912 & 0.9969 & 0.9955 \\
\hline \multirow[t]{2}{*}{35} & $\mathrm{Eq}$ & $y=0.8169 x-1.0717$ & $y=0.6129 x+1.836$ & $y=0.6087 x+1.8416$ & $y=0.5352 x+2.6042$ \\
\hline & $r$ & 0.9645 & 0.9990 & 0.9952 & 0.9882 \\
\hline \multirow[t]{2}{*}{40} & $\mathrm{Eq}$ & $y=0.4549 x+3.643$ & $y=0.6129 x+1.836$ & $y=0.6087 x+1.8416$ & $y=0.5352 x+2.6042$ \\
\hline & $r$ & 0.9645 & 0.9989 & 0.9952 & 0.9882 \\
\hline \multicolumn{6}{|c|}{ R. leguminosarum versus total microflora } \\
\hline \multirow[t]{2}{*}{30} & $\mathrm{Eq}$ & $y=0.4645 x+0.522$ & $y=0.4767 x+0.71$ & $y=0.5366 x+0.3809$ & $y=0.5357 x-0.0458$ \\
\hline & $r$ & 0.977088 & 0.986813 & 0.982853 & 0.986813 \\
\hline \multirow[t]{2}{*}{35} & $\mathrm{Eq}$ & $y=0.549 x+0.6942$ & $y=0.5502 x+0.7619$ & $y=0.5293 x+1.1878$ & $y=0.4731 x+1.3852$ \\
\hline & $r$ & 0.992371 & 0.988231 & 0.973242 & 0.983412 \\
\hline \multirow[t]{2}{*}{40} & $\mathrm{Eq}$ & $y=0.5456 x+1.3712$ & $y=0.5949 x+0.9506$ & $y=0.6327 x+0.74$ & $y=0.5609 x+0.2452$ \\
\hline & $r$ & 0.960573 & 0.978162 & 0.978366 & 0.988737 \\
\hline
\end{tabular}

Eq: regression equation; $r$ : correlation coefficient.

the total microbial population in the vermicompost are dependents on each other. However, the competition between these two groups for nutrients requires further insight.

There are many studies focusing the increase of microbial population in earthworm-excreted or -processed material than the parent material. Recent developments in the country as well as at the global level is the application of detritivorous epigeic earthworms for organic manure/vermicompost production from biodegradable organic materials recovered from agricultural lands, agrobased industries, and municipal solid waste. This field of study is closely associated with earthworm microbe interaction. The quality of the manure or vermicompost depends on microorganisms associated with the process of decomposition. Earthworm activity is closely associated with microbial activity. Primarily moisture is playing a major role in microbial population maintenance as it has been reported by Prakash et al. [27] and Kaljeet et al. [28]. Tiunov and Scheu [29] have shown that earthworms deprive easily available carbon to microorganisms and availability of carbon increases effective mobilization of $\mathrm{N}$ and $\mathrm{P}$ by earthworms. Earthworms are mainly responsible for fragmentation and conditioning of the substrate, increasing 


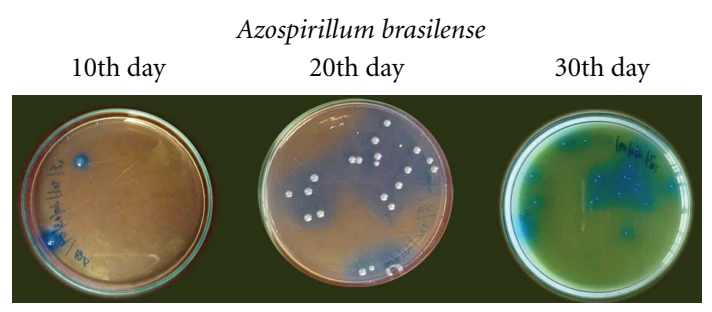

(a)

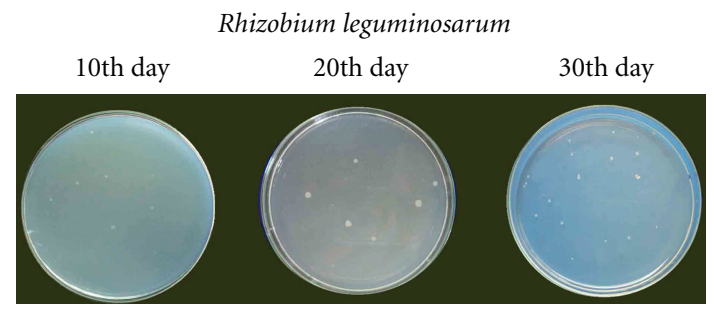

(b)

FIgURE 7: Survival of microbial inoculants $\left(\mathrm{CFU} \times 10^{7} \mathrm{~g}^{-1}\right)$ in vermicompost inoculated at the rate of $35 \mathrm{~mL} / \mathrm{g}$ substrate on different days of vermicomposting (10,20, and 30 days).

surface area for microbial activity, and significantly altering biological activity of the process [30]. The vermicasts when used as carrier material for biofertilizers supported the survival rate for more than one year [14]. The survival and increase of microbial population in vermicasts and wormworked compost (vermicompost) falls in line with present study results. The findings of the present study also showed similar results where the vermicompost served as a substrate for the survival and viability of the biofertilizer inoculants, A. brasilense and $R$. leguminosarum, for long period during storage.

\section{Conclusion}

The enhancement of nutrients and beneficial microbial population in the vermicompost is yet another important evolving trend where the vermicompost is value added with nutrients and or microorganisms resulting in improved growth and yield of crop plants. The inoculum level of $A$ brasilense. and $R$. leguminosarum at the rate of $35 \mathrm{~mL}$ per $175 \mathrm{~g}$ of vermibed substrate is sufficient to maintain $1 \times 10^{7}$ viable cells up to 160 days after harvesting of vermicompost. The inoculum of biofertilizer organisms into vermibed on the 30th day showed increased survival rate and hence, the optimized inoculation of $35 \mathrm{~mL}$ of inoculum per $175 \mathrm{~g}$ of substrate on the 30th of vermicomposting is helpful for the maintenance of sufficient viable population for more than five months in the enriched vermicompost.

\section{Conflict of Interests}

The authors declare that there is no conflict of interests.

\section{References}

[1] C. A. Edwards, Earthworm Ecology, CRC Press, Boca Raton, Fla, USA, 2nd edition, 2004.

[2] A. A. Ansari, "Worm powered environmental biotechnology in organic waste management," International Journal of Soil Science, vol. 6, no. 1, pp. 25-30, 2011.

[3] J. G. Zaller, "Vermicompost as a substitute for peat in potting media: effects on germination, biomass allocation, yields and fruit quality of three tomato varieties," Scientia Horticulturae, vol. 112, no. 2, pp. 191-199, 2007.

[4] M. Jayakumar, T. Sivakami, D. Ambika, and N. Karmegam, "Effect of turkey litter (Meleagris gallopavo L.) vermicompost on growth and yield characteristics of paddy, Oryza sativa (ADT-37)," African Journal of Biotechnology, vol. 10, no. 68, pp. 15295-15304, 2011.

[5] R. K. Sinha, S. Agarwal, K. Chauhan, V. Chandran, and B. K. Soni, "Vermiculture technology: reviving the dreams of Sir Charles Darwin for scientific use of earthworms in sustainable development programs," Journal of Technology and Investment, vol. 1, no. 3, pp. 155-172, 2010.

[6] M. Aira, F. Monroy, and J. Domínguez, "Earthworms strongly modify microbial biomass and activity triggering enzymatic activities during vermicomposting independently of the application rates of pig slurry," Science of the Total Environment, vol. 385, no. 1-3, pp. 252-261, 2007.

[7] C. A. Barassi, R. J. Sueldo, C. M. Creus, L. E. Carrozzi, E. M. Casanovas, and M. A. Pereyra, "Azospirillum spp., a dynamic soil bacterium favourable to vegetable crop production," Dynamic Soil, Dynamic Plant, vol. 1, no. 2, pp. 68-82, 2007.

[8] A. A. Abo-Baker and G. G. Mostafa, "Effect of bio-and chemical fertilizers on growth, sepals yield and chemical composition of Hibiscus sabdariffa at new reclaimed soil of South Valley area," Asian Journal of Crop Science, vol. 3, no. 1, pp. 16-25, 2011.

[9] V. V. Geetha and P. Balamurugan, "Organic seed pelleting in mustard," Research Journal of Seed Science, vol. 4, no. 3, pp. 174-180, 2011.

[10] O. P. Jangu and S. S. Sindhu, "Differential response of inoculation with indole acetic acid producing Pseudomonas sp. in green gram (Vigna radiata L.) and black gram (Vigna mungo L.)," Microbiology Journal, vol. 1, no. 5, pp. 159-173, 2011.

[11] J. P. Verma, J. Yadav, and K. N. Tiwari, "Application of Rhizobium sp. BHURC01 and plant growth promoting rhizobactria on nodulation, plant biomass and yields of chickpea (Cicer arietinum L.)," International Journal of Agricultural Research, vol. 5, no. 3, pp. 148-156, 2010.

[12] A. I. Fahmi, H. H. Nagaty, R. A. Eissa, and M. M. Hassan, "Effects of salt stress on some nitrogen fixation parameters in faba bean," Pakistan Journal of Biological Sciences, vol. 14, no. 6, pp. 385-391, 2011.

[13] A. K. Singh, Gauri, R. P. Bhatt, and S. Pant, "Optimization and comparative study of the sugar waste for the growth of Rhizobium cells along with traditional laboratory media," Research Journal of Microbiology, vol. 6, no. 9, pp. 715-723, 2011.

[14] K. Raja Sekar and N. Karmegam, "Earthworm casts as an alternate carrier material for biofertilizers: assessment of endurance and viability of Azotobacter chroococcum, Bacillus megaterium and Rhizobium leguminosarum," Scientia Horticulturae, vol. 124, no. 2, pp. 286-289, 2010.

[15] N. Q. Arancon and C. A. Edwards, "The utilization of vermicomposts in horticulture and agriculture," in Proceedings of Indo-US Workshop on Vermitechnology in Human Welfare, 
C. A. Edwards, R. Jayaraaj, and I. A. Jayraaj, Eds., pp. 98-108, Rohini Achagam, Coimbatore, India, 2009.

[16] P. Lavelle, "The structure of earthworm communities," in Earthworm Ecology, J. E. Satchell, Ed., pp. 449-466, Chapman and Hall, London, UK, 1983.

[17] A. Singh and S. Sharma, "Composting of a crop residue through treatment with microorganisms and subsequent vermicomposting," Bioresource Technology, vol. 85, no. 2, pp. 107111, 2002.

[18] A. S. Anilkumar, K. H. Nair, and A. K. Sherief, "Utilization of enriched coirpith-vermicompost in organic mediculture," Plant Archives, vol. 7, pp. 617-620, 2007.

[19] K. Hashemimajd and A. Golchin, "The effect of iron-enriched vermicompost on growth and nutrition of tomato," Journal of Agricultural Science and Technology, vol. 11, no. 5, pp. 613-621, 2009.

[20] R. Kumar, D. Verma, B. L. Singh, U. Kumar, and Shweta, "Composting of sugar-cane waste by-products through treatment with microorganisms and subsequent vermicomposting," Bioresource Technology, vol. 101, no. 17, pp. 6707-6711, 2010.

[21] T. Daniel, B. Sivasankari, and M. Malathy, "Microbial and nutrient enhancement of Gliricidia sepium and Leucaena leucocephala leaf materials using Eisenia fetida," in Vermitechnology II, N. Karmegam, Ed., vol. 4, no. 1, pp. 152-154, Dynamic Soil, Dynamic Plant, 2010.

[22] S. J. Veeresh, J. Narayana, and J. A. Teixeira da Silva, "Influence of Jeevamrutha (biodynamic formulation) on agroindustrial waste vermicomposting," in Vermitechnology II, N. Karmegam, Ed., vol. 4, pp. 96-99, Dynamic Soil, Dynamic Plant, 2010.

[23] V. Kumar and K. P. Singh, "Enriching vermicompost by nitrogen fixing and phosphate solubilizing bacteria," Bioresource Technology, vol. 76, no. 2, pp. 173-175, 2001.

[24] P. K. Padmavathiamma, L. Y. Li, and U. R. Kumari, "An experimental study of vermi-biowaste composting for agricultural soil improvement," Bioresource Technology, vol. 99, no. 6, pp. 1672-1681, 2008.

[25] R. Kumar and Shweta, "Enhancement of wood waste decomposition by microbial inoculation prior to vermicomposting," Bioresource Technology, vol. 102, no. 2, pp. 1475-1480, 2011.

[26] P. H. Rasal, H. B. Kalbhor, V. V. Shingte, and P. L. Patil, "Development of technology for rapid composting and enrichment," in Biofertilizers, Potentialities and Problems, S. P. Sen and P. Palit, Eds., pp. 255-258, Plant Physiology Forum and Naya Prakash, Calcutta, India, 1988.

[27] M. Prakash, M. Jayakumar, and N. Karmegam, "Physicochemical characteristics and fungal flora in the casts of the earthworm, Perionyx ceylanensis Mich. Reared in Polyalthia longifolia leaf litter," Journal of Applied Sciences Research, vol. 4, no. 1, pp. 53-57, 2008.

[28] S. Kaljeet, F. Keyeo, and H. G. Amir, "Influence of carrier materials and storage temperature on survivability of Rhizobial inoculant," Asian Journal of Plant Sciences, vol. 10, no. 6, pp. 331-337, 2011.

[29] A. V. Tiunov and S. Scheu, "Carbon availability controls the growth of detritivores (Lumbricidae) and their effect on nitrogen mineralization," Oecologia, vol. 138, no. 1, pp. 83-90, 2004.

[30] J. Domínguez, W. Parmelee, and C. A. Edwards, "Interactions between Eisenia andrei (Oligochaeta) and nematode populations during vermicomposting," Pedobiologia, vol. 47, no. 1, pp. 53-60, 2003. 

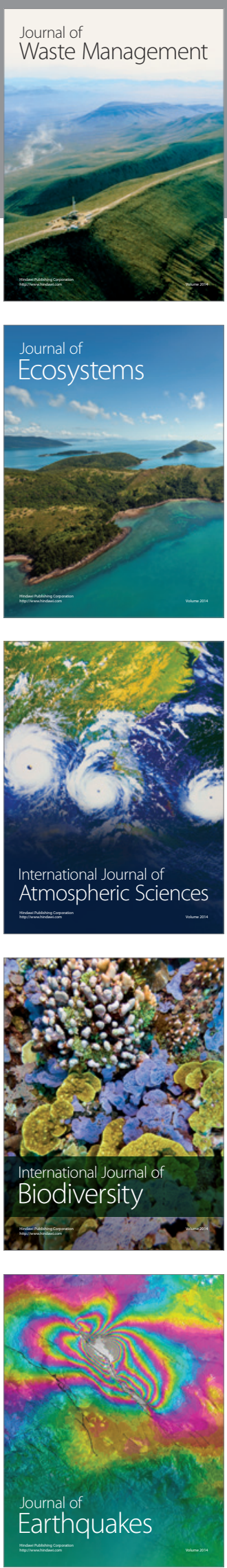
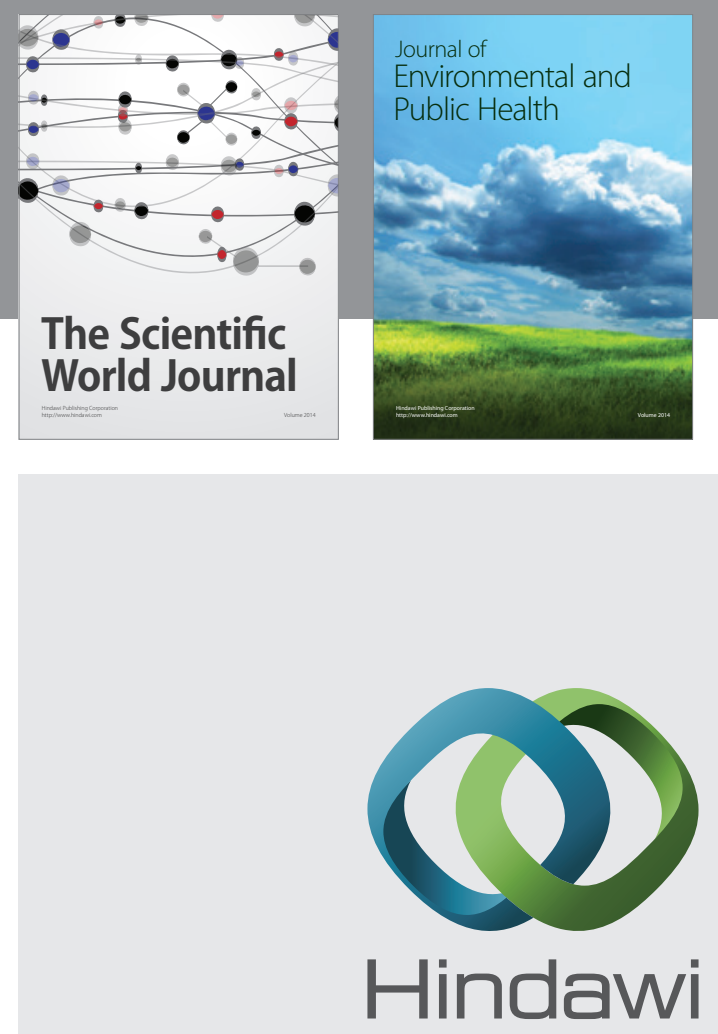

Submit your manuscripts at

http://www.hindawi.com
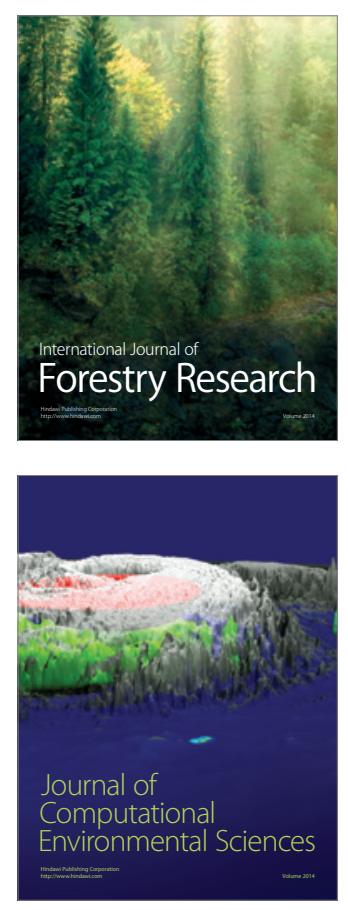
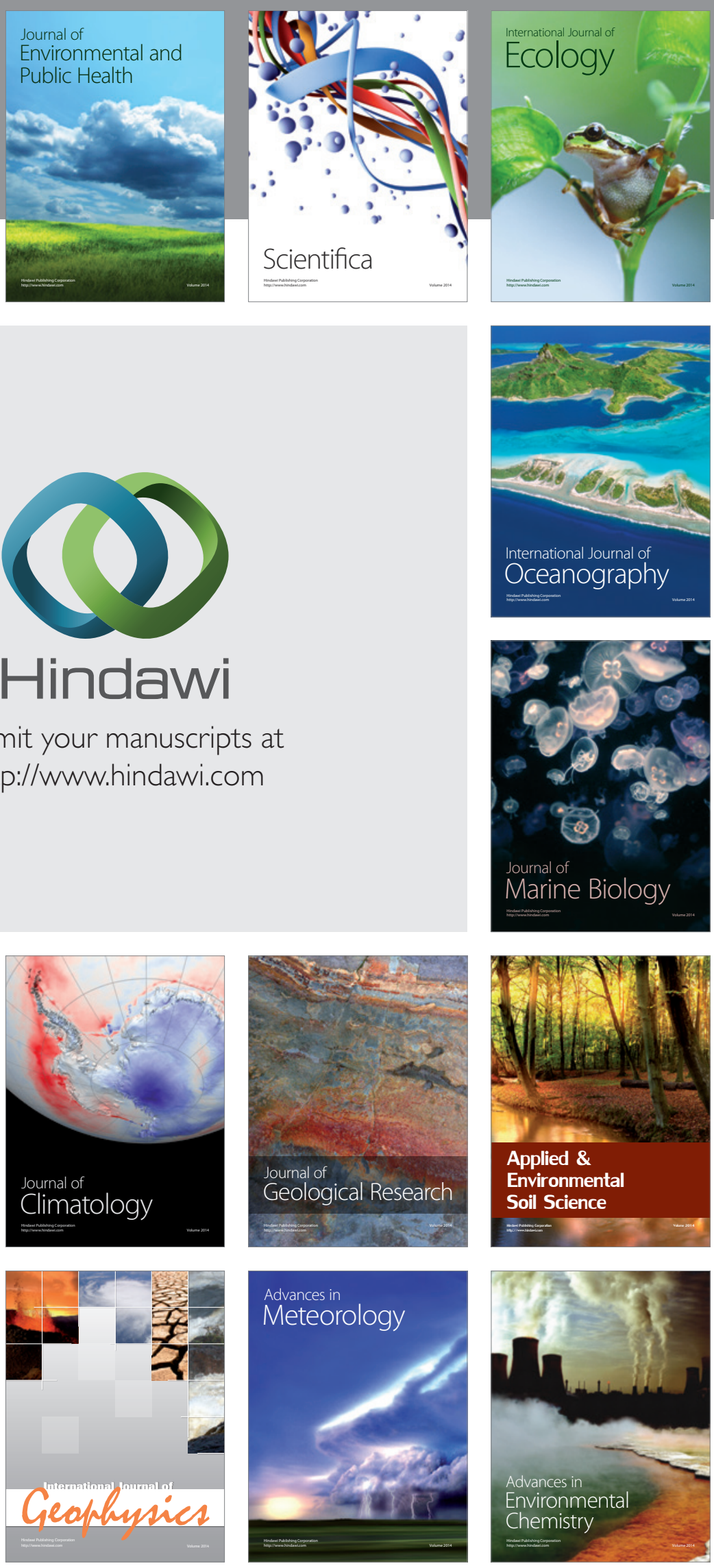